\title{
Carbon Nanotubes Innovate on Medical Technology
}

\author{
Yuki Usui', Hisao Haniu², Shuji Tsuruoka ${ }^{1}$ and Naoto Saito ${ }^{3 *}$
}

${ }^{1}$ Research Center for Exotic Nanocarbons, Shinshu University, 4-17-1 Wakasato Nagano 380-8553, Japan

${ }^{2}$ Department of Orthopaedic Surgery, Shinshu University School of Medicine, 3-1-1 Asahi, Matsumoto, Nagano, 390-8621, Japan

${ }^{3}$ Department of Applied Physical Therapy, Shinshu University School of Health Sciences, 3-1-1 Asahi, Matsumoto, Nagano, 390-8621, Japan

\begin{abstract}
Carbon nanotubes (CNTs) possess exceptional mechanical and electrical properties, therefore researches and developments are performed in various fields. In recent years application to the medical field of CNTs attracted attention, and a large number of studies have begun to be performed. An applied study to cancer diagnosis and treatment, and a study to use for scaffold for regenerative medicine, besides, a study to compound in CNTs for the improvement of the function and durability of conventional biomaterials. In the applied study that properties of all CNTs were fully made use of in, development in the future is expected. In this review, we state it about the contents of a performed study for medical application of CNTs now, and introduce in particular the basic studies that are performed to apply CNTs to biomaterials in detail.
\end{abstract}

Keywords: Carbon nanotubes; Medical application; Cancer treatment; Regenerative medicine; Biomaterials

\section{Introduction}

Carbon Nanotubes (CNTs) are fibrous carbon materials with a cylindrical structure of the nanometer order in diameter $\left(10^{-9} \mathrm{~m}\right)$, where each cylinder forms from a rolled graphene sheet consisting of a honeycomb of benzene rings in the same plane. Oberlin et al. first reported CNTs in 1976 [1]. As CNTs have novel characteristics, such as mechanical strength, thermal resistance, and high electrical and thermal conductivities, they have been applied in many fields [3-7]. There is increasing interest in their medical applications. Many of these applications are related to diagnosis and therapy of cancer [8-12], application as scaffolds for regeneration [13-17], and for enhancing the performance of existing biomaterials $[18,19]$. These studies made good use of the characteristics of CNTs (Figure 1), and are expected to make significant progress. Here, we summarize the current medical applications of CNTs and present details of our basic research work.

\section{Application if CNTs in Cancer Therapy}

The most important considerations in cancer therapy are to find the lesion and achieve complete cure. A number of methods for finding cancer cells, such as imaging studies (Computed Tomography (CT), Magnetic Resonance Imaging (MRI), Positron Emission Tomography (PET)) and use of tumor markers, have been developed for early diagnosis. However, it is difficult to specify all cancers in the subclinical stage, and many cases are identified at the terminal stage. To improve this situation, the electronic, mechanical, and thermal characteristics of CNTs are expected to be useful for early diagnosis by detecting molecules associated with early cancer cells. Improvements of sensing capability of Prostate Specific Antigen (PSA) [20,21], Carcinoembryonic Antigen (CEA) [22,23], Carbohydrate antigen (CA)19-9 [24,25], and AlphaFetoprotein (AFP) [26,27] have been reported. These results suggest the possibility of very early diagnosis using CNTs.

Although several methods, including chemotherapy, radiotherapy, thermotherapy, and gene therapy, are applicable to cure cancers, each of these methods has a number of disadvantages. For example, chemotherapy has a number of adverse effects due to the systemic administration of medications, which results in difficulty of targeting a particular organ. On the other hand, medicines, peptides, nucleic acids, and other useful molecules can be attached to the edges and/or surface of CNTs due to their large specific surface [12]. Furthermore, functionalized CNTs can permeate through cell membranes via biological mechanisms such as endocytosis by which materials are introduced into cells [28]. Using this mechanism, it may be possible to target these molecules specifically to cancer cells by use of cell recognition by peptides and/or ligands on CNTs that selectively bind to receptors [29]. An ideal Drug Delivery System (DDS) can deliver the necessary amount of material to the target site with the appropriate timing, and CNTs can potentially fulfill these requirements. It is also predicted that CNTs will be useful for gene therapy [30-33].

CNTs generate heat by microwave emission [34-36]. This may cause cell damage due to excess heat without appropriate regulation of energy output and protocols must be designed carefully.

\section{Regenerative Medicine}

Regenerative medicine involves the regeneration of disease- and/ or injury-damaged organs and tissues using artificially developed cells and tissues. This has become an area of active research since the first report of induced Pluripotent Stem cells (iPS cells) in 2007 [37]. It is important to introduce an appropriate scaffold because tissues are induced to generate by cells, genes, and proteins, such as cytokines or growth factors.

There have been several previous reports regarding such scaffolds. Vascular endothelial cells show not only proliferation but also regulate thrombogenesis on CNT/polycarbonate urethane composite scaffolds [38]. CNTs have been used as scaffolds for neuronal proliferation [3941].

$\mathrm{CNT} /$ polycarbonate urethane composite films have shown good results for chondrocytic adhesion and cartilage regeneration [42]. Combination of collagen with CNTs improves the properties as scaffold $[43,44]$. In addition to the studies mentioned above, it has been reported that CNTs can effectively enhance neurogenic cell differentiation by embryonic stem cells [45]. These observations suggested the

*Corresponding author: Naoto Saito, Department of Applied Physical Therapy, Shinshu University School of Health Sciences, 3-1-1 Asahi, Matsumoto, Nagano, 390-8621, Japan, Tel: 81-263-37-2659; Fax: 81-263-35-8844; E-mail: saitoko@shinshu-u.ac.jp

Received January 30, 2012; Accepted February 22, 2012; Published February 23, 2012

Citation: Usui Y, Haniu H, Tsuruoka S, Saito N (2012) Carbon Nanotubes Innovate on Medical Technology. Med chem 2: 001-006. doi:10.4172/2161-0444.1000105

Copyright: (c) 2012 Usui Y, et al. This is an open-access article distributed under the terms of the Creative Commons Attribution License, which permits unrestricted use, distribution, and reproduction in any medium, provided the original author and source are credited. 
effectiveness of CNTs as scaffolds in regenerative medicine. In addition, there have been reports of similar effects in regeneration of bone tissue [46-53]. Our exploratory work has indicated the effects of CNTs in bone formation as described in Section 5 below.

\section{Biomaterials}

Biomaterials are those that make contact with living tissues, including cells. The table 1 lists the major biomaterials that have been developed to date (Japan Society of Medical Electronics and Biological Engineering, 1999) [54]. However, these materials have unresolved disadvantages, such as the lack of durability of artificial organs. Here, we will present a discussion of biomaterials used for plastic surgery.

Various materials are used for treatment of fractures, including plates, screws, wires, artificial joints, etc. Titanium composite used for osteosynthesis surgery shows good bone-tissue compatibility and has good weight characteristics. However, it must have a certain thickness to compensate for the strength required to withstand bendingstretching motion. The thickness of such implants is often problematic for patients. In addition, such plates sometimes show deterioration following rupture. Thus, lighter and tougher Ti composite is required. Polyethylene, which is used for sliding parts of artificial joints, has problems related to abrasion. The micropowders generated by wear of polyethylene during its long-term use are phagocytosed by macrophages, which causes the release of inflammatory cytokines, such as Tumor Necrosis Factor (TNF)- $\alpha$, Interleukin (IL)- $1 \beta$, and IL-6. These molecules then induce osteoclast formation resulting in osteolysis around the implant. As a result, the artificial joint may then become loose [55]. However, ceramic components used in the sliding parts of artificial joints are resistant to abrasion but are prone to breakage with repeated impact (Figure 2) [56-58]. In both cases, a second operation is required to correct the problems that arise.

To improve the above cases, we are developing materials strengthening with CNTs as a reinforcing agent to extend the lives of such implants [59]. Indeed, the number of patients requiring a second operation has increased dramatically over the past several years; our objective is to reduce the number of reoperations using CNT polyethylene composite and/or CNT ceramic composite biomaterials to significantly prolong the life of implants. Note that it is necessary to evaluate the affinity of CNTs to bone in these applications, which is shown as in vivo test in Section 5.

\section{Influence of CNTs on Bone Tissues}

We introduce in particular the basic studies that are performed to apply CNTs to bone tissue regeneration and biomaterials in contact with bone [60].

\section{Materials used in this evaluation}

Multi-walled carbon nanotubes with an average diameter of 80 $\mathrm{nm}$, length of $10-20 \mu \mathrm{m}$, and $99.9 \%$ purity as carbon synthesized by the Chemical Vapor Deposition (CVD) method were obtained from Showa Denko (VGNF; Tokyo, Japan). Graphite with an average particle diameter of $4 \mathrm{~m}$ obtained from ITO Graphite Inc. (X-3M; Mie, Japan) was used as a control. Tween 80 (Polysorbate 80) as a surfactant was obtained from NOF Inc. (NOFABLE-9920HX; Tokyo, Japan).

\section{Experimental methods and results}

Subperiosteal experiment: The periosteum of the skull of male ddY mice (6 weeks old) was opened and the CNT solution was instilled subperiosteally by injection. As a sham operation control, isotonic sodium chloride solution with the surfactant was instilled into another

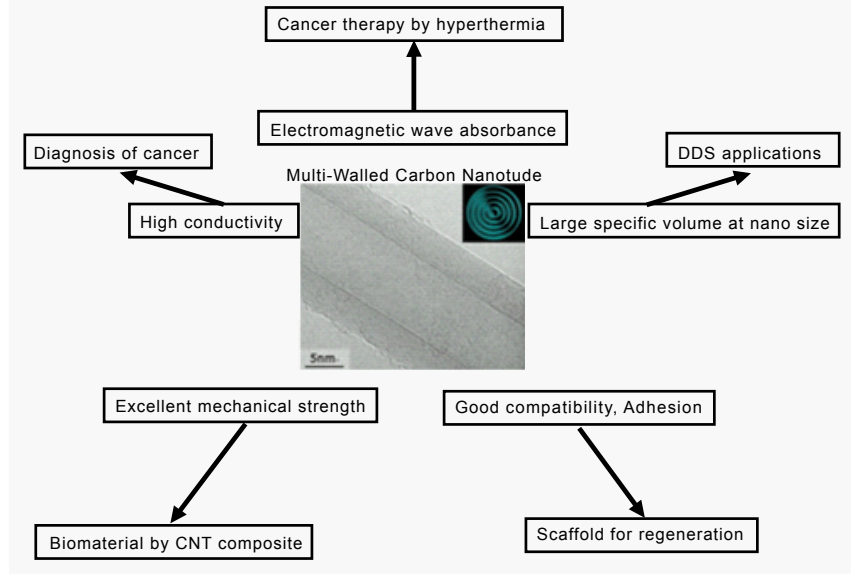

Figure 1: Characteristics of Carbon nanotubes and medical applications.

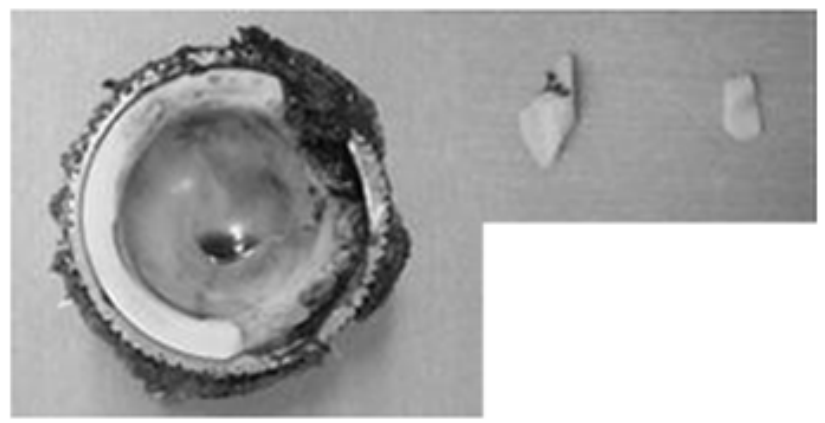

Figure 2: Damaged ceramics removed at second operation.

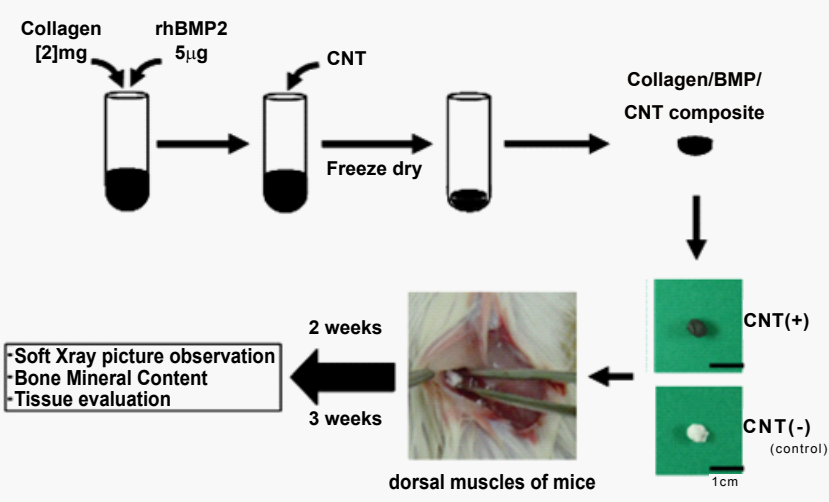

Figure 3: Scheme of bone formation experiment.

group of mice. To make tissue slice samples, mice from each group were sacrificed at 1 and 4 weeks, and the skulls were removed. The samples were fixed, decalcified, and cut into sections, which were stained and observed by light microscopy.

The sham group showed recovery of the bone tissues after 1 week of exposure and very minor inflammation was seen. After 4 weeks, the bone tissues were restored completely. The CNT group showed 


\begin{tabular}{|c|c|c|}
\hline Organ & Term & Major materials \\
\hline \multirow[t]{2}{*}{ Eyes } & Contact lens & PMMA, MPC polymer \\
\hline & Intraocular lens & PMMA \\
\hline \multirow[t]{2}{*}{ Teeth } & Artificial tooth, Dental prosthesis & PMMA \\
\hline & Cavity fill material & Methacryl acid derivative polymer \\
\hline Esophagus & Artificial esophagus & Polyethylene / Natural rubber \\
\hline \multirow[t]{2}{*}{ Heart } & Mechanical heart & Segmented polyurethane \\
\hline & Prosthetic cardiac valve & Pylorite carbon \\
\hline Lungs & $\begin{array}{l}\text { Oxygenator } \\
\text { (extracorporeal circulation) }\end{array}$ & Porous polypropylene \\
\hline Mamma & Mammary prostheses & Silicone \\
\hline Liver & Artificial liver & Activated carbon, Porous polymer beads \\
\hline Kidney & Artificial kidney & Cellulose, PMMA, Polysulfone \\
\hline $\begin{array}{l}\text { Blood } \\
\text { vessel }\end{array}$ & Artificial vessel & Stretched PTFE \\
\hline Hip joint & $\begin{array}{l}\text { Artificial joint } \\
\text { (the part of main body) }\end{array}$ & $\begin{array}{l}\text { Titanium alloy, Cobalt-chromium alloy, } \\
\text { Ceramics (Alumina, Zirconia) }\end{array}$ \\
\hline Knee joint & Artificial joint (articular part) & Ultra high molecular weight polyethylene \\
\hline $\begin{array}{l}\text { Phalangeal } \\
\text { joint }\end{array}$ & Artificial finger joint & Silicone \\
\hline Ligament & Artificial ligament & Polyester, PTFE \\
\hline \multirow[t]{2}{*}{ Bone } & Artificial bone & Hydroxyapatite \\
\hline & Bone cement & PMMA \\
\hline
\end{tabular}

Table 1: Major biomaterials. Modificaton from ref [54].

tissue recovery after 1 week of exposure, similar to the sham group. CNT particles remained in the subperiosteum and resulted in minimal inflammation, while slight lymphocyte and fibroblast infiltrates were seen. Macrophages accumulated around the CNT particles. After 4 weeks, the CNT group showed complete subperiosteal restoration. CNT particles and macrophages after phagocytosis of the particles remained in the subperiosteum. Inflammation was reduced compared to that seen after 1 week of exposure, while no osteolysis was seen at CNT contact points.

These results indicated that CNTs did not cause severe inflammation or osteolysis at the CNT contact points, and showed good biocompatibility with the bone tissues.

Bone healing experiment: A hole was drilled in the left tibial diaphysis of male ddY mice ( 6 weeks old) $0.7 \mathrm{~mm}$ in diameter and $2 \mathrm{~mm}$ in depth using Kirschner wire. The same CNT solution as described above was injected into the hole. The sham operation group was treated similarly except graphite solution was injected into the hole.

The sham group showed significant bone formation at the hole after 1 week of exposure, and the hole had healed completely after 4 weeks. The graphite group showed insufficient healing in comparison with the sham group after 1 week of exposure, where the graphite particles remained inside the bone marrow only and were not taken up into the newly healed bone matrix. Bone healing was markedly stunted after 4 weeks of exposure, when the cortical and trabecular bone did not heal to the original thickness. Graphite particles remained within the bone marrow but were not taken up into the matrix. The CNT group showed the same rate of bone healing as the sham group, and CNTs were taken up into the new bone matrix. After 4 weeks, the cortical bone and bone marrow were healed completely and the CNTs were taken up into not only the bone marrow but also into the bone matrix.

These experiments indicated that CNTs were taken up and came into direct contact with the bone matrix without any inhibition of repair. Therefore, CNTs showed high biocompatibility with bone matrix similar to the subperiosteum experiments.
Ectopic bone formation experiments using bone morphogenetic protein: Recombinant human Bone Morphogenetic Protein 2 (rhBMP2) deposited on collagen as carrier and implanted under the dorsal muscle of mice gives rise to ectopic ossification and heterotopic bone formation $[61,62]$. Using this assay, freeze-dried pellets were made with a mixture of $2 \mathrm{mg}$ of atelopeptide type 1 collagen including 5 $\mu \mathrm{g}$ of rhBMP2 and $500 \mu \mathrm{g}$ of CNTs. Control pellets were made without the CNTs. The pellets were implanted under the dorsal muscles of male ddY mice ( 5 weeks old, 16 mice per group). Eight animals in each group were sacrificed at 2 and 3 weeks postimplantation, and the heterotopic bones were removed (Figure 3 ). These bones were analyzed by soft $\mathrm{X}$-ray analysis, observation of those tissue samples and Bone Mineral Content (BMC) was determined using a bone mineral analyzer.

The soft X-ray pictures of heterotopic bones 2 weeks postimplantation showed significantly larger bone shadows and higher BMCs than the controls $(P=0.016)$. The tissue samples in both groups showed enchondral ossification with the same extent of maturation. CNTs were taken up into the bone matrices of newly formed bones, similar to the bone healing experiment described above. At 3 weeks postimplantation, there was no difference in bone shadow between the two groups on soft X-ray pictures. BMC of the CNT group was higher than that of the control group, but the difference was not statistically significant $(P=0.41)$. There was no difference in those tissue samples at 3 weeks postimplantation, while trabecular structures and bone marrow growth were seen by observed along with normal bone growth (Figure 4).

In this experiment, CNTs accelerated ectopic bone formation by rhBMP2 and the CNT particles were taken up and came into direct contact with the new bone matrix.

Hydroxyapatite crystallization test: The contents of crystals formed from standing CNT solution in Phosphate Buffered Saline (PBS) (+) at $37^{\circ} \mathrm{C}$, which was sonicated, were analyzed by X-Ray Diffraction (XRD) [63]. The crystal shapes at 6 h, 2 days, and 2 weeks of standing at $37^{\circ} \mathrm{C}$ were examined by FE-SEM. 

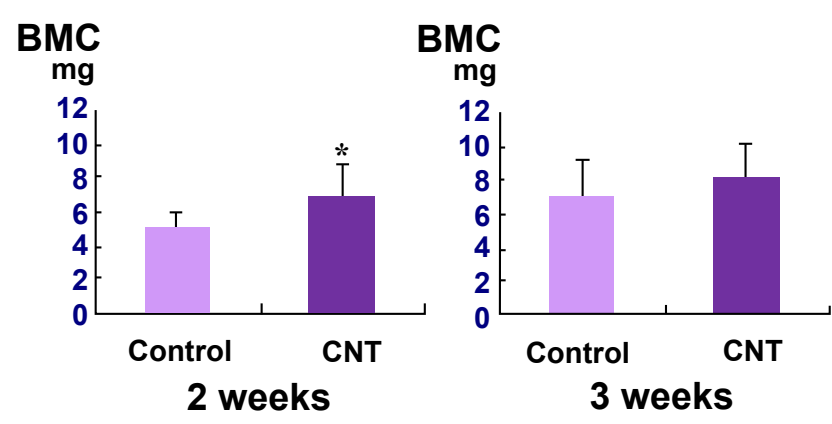

${ }^{*} p=0.016$. Modification from ref. [60]

Figure 4: Bone Mineral Content (BMC) of the heterotopic bones removed at 2 or 3 weeks after implantation. BMC was high at 2 weeks, and significant bone growth was seen.

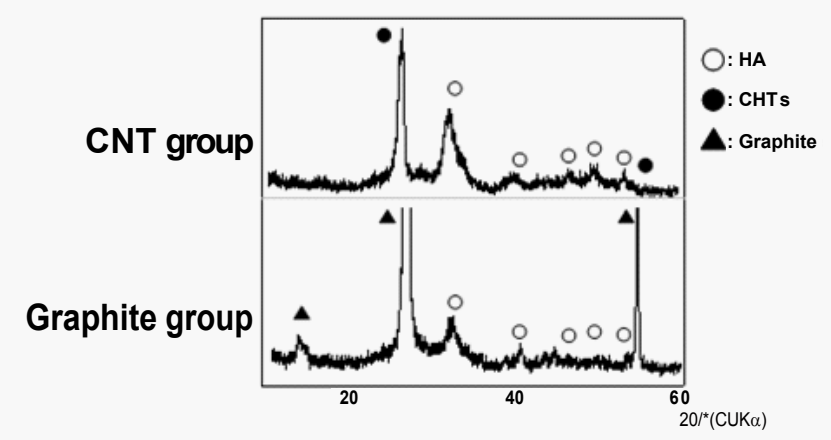

Figure 5: XRD results for HA crystallization experiments, both groups showed the peaks identical to HA. From ref. [60].

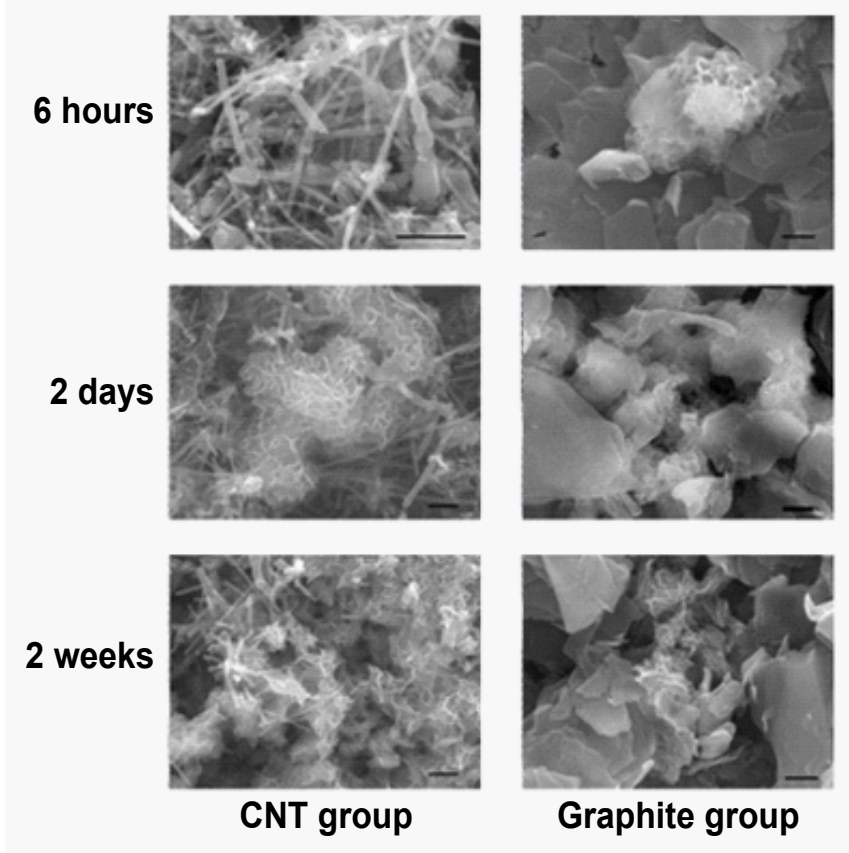

Figure 6: SEM observations of HA crystallization test.
The crystals in both the CNT and graphite control groups were shown to be hydroxyapatite (HA) based on the corresponding peaks (Figure 5).

SEM observations indicated that ball-shaped crystals formed over the CNT surfaces after $6 \mathrm{~h}$, the coralline form was observed after 2 days, and crystal growth was seen after 2 weeks. On the other hand, the graphite group showed separation of cotton ball-like crystals after $6 \mathrm{~h}$. The growth rate was much lower in the graphite group than in the CNT group (Figure 6).

Extensive HA crystallization was observed using CNTs as the nuclei in PBS (+) solution. As bone formation occurs through calcification of HA deposits on the bone matrix consisting of collagen secreted by osteoblasts, these results indicated that HA crystallization occurred around CNTs as nuclei and enhanced bone formation in PBS (+) solution.

These results indicated that CNTs have good bone tissue compatibility and do not inhibit bone healing. CNTs were included in the bone matrix of newly formed bone. Furthermore, CNTs promoted and enhanced bone formation, as HA crystallization was promoted by CNTs as nuclei. These results indicated that CNTs have advantages for use as biomaterials that come into contact with the bone matrix and therefore may be effective as scaffolds in regenerative medicine.

\section{Conclusions}

Medical applications of CNTs were discussed based on their influence on bone tissues. CNTs are currently under investigation for application as DDS, biosensors, and other uses based on their unique characteristics, and are anticipated to be advantageous in medical applications. CNTs show good biocompatibility with tissues, particularly bone tissues, and therefore CNTs have been applied in new medical composites and scaffolds for regenerative medicine. The most important consideration for medical application is safety. The results of several evaluations have been reported, but there is still insufficient qualitative and quantitative information regarding their safety [6471]. Very recently, we reported that carbon nanotubes for use as biomaterials have basic safety properties comparable to an optimal nano-sized reference material [72].

As CNTs have great potential for use in medical technology, further studies to determine their safety and most suitable applications are urgently required.

\section{Acknowledgment}

This work was supported by the CLUSTER (the second stage) of the Ministry of Education, Culture, Sports, Science, and Technology of Japan, and Grant-in-Aid for Specially Promoted Research from the Ministry of Education, Culture, Sports, Science and Technology of Japan (No. 19002007).

\section{References}

1. Oberlin A, Endo M, Koyama T (1976) Filamentous growth of carbon through benzene decomposition. J Cryst Growth 32: 335-349.

2. lijima S (1991) Helical micortubules of graphitic carbon. Nature 354: 56-58.

3. Van Noorden R (2011) Chemistry: the trials of new carbon. Nature 469: 14-16

4. Xiong F, Liao AD, Estrada D, Pop E (2011) Low-power switching of phasechange materials with carbon nanotube electrodes. Science 332: 568-570.

5. Qu L, Dai L, Stone M, Xia Z, Wang ZL (2008) Carbon nanotube arrays with strong shear binding-on and easy normal lifting-off. Science 322: 238-242.

6. Shannon MA, Bohn PW, Elimelech M, Georgiadis JG, Mariñas BJ, et al. (2008) Science and technology for water purification in the coming decades. Nature 452: 301-310.

7. Baughman RH, Zakhidov AA, de Heer WA (2002) Carbon nanotubes--the route toward applications. Science 297: 787-792. 
8. Yang F, Jin C, Yang D, Jiang Y, Li J, et al. (2011) Magnetic functionalised carbon nanotubes as drug vehicles for cancer lymph node metastasis treatment. Europ J Cancer 47: 1873-1882.

9. Chaudhuri P, Harfouche R, Soni S, Hentschel DM, Sengupta S (2010) Shape effect of carbon nanovectors on angiogenesis. ACS Nano 4: 574-582.

10. Ruggiero A, Villa CH, Holland JP, Sprinkle SR, May C, et al. (2010) Imaging and treating tumor vasculature with targeted radiolabeled carbon nanotubes. Int J Nanomedicine 5: 783-802.

11. Singh S (2010) Nanomedicine-nanoscale drugs and delivery systems. J Nanosci Nanotechnol 10: 7906-7918.

12. Bhirde AA, Patel V, Gavard J, Zhang G, Sousa AA, et al. (2009) Targeted killing of cancer cells in vivo and in vitro with EGF-directed carbon nanotube-based drug delivery. ACS Nano 3: 307-316.

13. Dvir T, Timko BP, Kohane DS, Langer R (2011) Nanotechnological strategies for engineering complex tissues. Nat Nanotechnol 6: 13-22.

14. Tran PA, Zhang L, Webster TJ (2009) Carbon nanofibers and carbon nanotubes in regenerative medicine. Adv Drug Deliver Rev 61: 1097-1114.

15. Zhang L, Webster TJ (2009) Nanotechnology and nanomaterials: Promises for improved tissue regeneration. Nanotoday 4: 66-80.

16. Abarrategi A, Gutiérrez MC, Moreno-Vicente C, Hortigüela MJ, Ramos V, et al. (2008) Multiwall carbon nanotube scaffolds for tissue engineering purposes. Biomaterials 29: 94-102.

17. Harrison BS, Atala A (2007) Carbon nanotube applications for tissue engineering. Biomaterials 28: 344-353.

18. Arnould C, Korányi TI, Delhalle J, Mekhalif Z (2010) Fabrication of tantalum oxide/carbon nanotubes thin film composite on titanium substrate. J Colloid Interface Sci 344: 390-394

19. Webster TJ, Waid MC, McKenzie JL, Price RL, Ejiofor JU (2004) Nanobiotechnology: carbon nanofibres as improved neural and orthopaedic implants. Nanotechnology 15: 48 .

20. Kim JP, Lee BY, Lee J, Hong S, Sim SJ (2009) Enhancement of sensitivity and specificity by surface modification of carbon nanotubes in diagnosis of prostate cancer based on carbon nanotube field effect transistors. Biosens Bioelectron 24: $3372-3378$

21. Li C, Curreli M, Lin H, Lei B, Ishikawa FN, et al. (2005) Complementary detection of prostate-specific antigen using $\ln 2 \mathrm{O} 3$ nanowires and carbon nanotubes. J Am Chem Soc 127: 12484-12485.

22. Gao X, Zhang Y, Chen H, Chen Z, Lin X (2011) Amperometric immunosensor for carcinoembryonic antigen detection with carbon nanotube-based film decorated with gold nanoclusters. Anal Biochem 414: 70-76.

23. Li Q, Tang D, Tang J, Su B, Huang J, et al. (2011) Carbon nanotube-based symbiotic coaxial nanocables with nanosilica and nanogold particles as labels for electrochemical immunoassay of carcinoembryonic antigen in biological fluids. Talanta 84: 538-546.

24. Ding Y, Liu J, Jin X, Lu H, Shen G, et al. (2008) Poly-L-lysine/hydroxyapatite/ carbon nanotube hybrid nanocomposite applied for piezoelectric immunoassay of carbohydrate antigen 19-9. Analyst 133: 184-190.

25. Ou C, Yuan R, Chai Y, Tang M, Chai R, et al. (2007) A novel amperometric immunosensor based on layer-by-layer assembly of gold nanoparticles-multiwalled carbon nanotubes-thionine multilayer films on polyelectrolyte surface. Anal Chim Acta 603: 205-213

26. Bi S, Zhou H, Zhang S (2009) Multilayers enzyme-coated carbon nanotubes as biolabel for ultrasensitive chemiluminescence immunoassay of cancer biomarker. Biosens Bioelectron 24: 2961-2966

27. Lin J, He C, Zhang L, Zhang S (2009) Sensitive amperometric immunosensor for alpha-fetoprotein based on carbon nanotube/gold nanoparticle doped chitosan film. Anal Biochem 384: 130-135.

28. Zhang X, Meng L, Lu Q, Fe, Z, Dyson PJ (2009) Targeted delivery and controlled release of doxorubicin to cancer cells using modified single wall carbon nanotubes. Biomaterials 30: 6041-6047.

29. Chen J, Chen S, Zhao X, Kuznetsova LV, Wong SS, et al. (2008) Functionalized single-walled carbon nanotubes as rationally designed vehicles for tumortargeted drug delivery. J Am Chem Soc 130: 16778-16785.

30. Herrero MA, Toma FM, Al-Jamal KT, Kostarelos K, Bianco A, et al. (2009)
Synthesis and characterization of a carbon nanotube-dendron series for efficient siRNA delivery. J Am Chem Soc 131: 9843-9848.

31. Podesta JE, Al-Jamal KT, Herrero MA, Tian B, Ali-Boucetta H, et al. (2009) Antitumor activity and prolonged survival by carbon-nanotube-mediated therapeutic siRNA silencing in a human lung xenograft model. Small 5: 11761185.

32. Singh R, Pantarotto D, McCarthy D, Chaloin O, Hoebeke J, et al. (2005) Binding and condensation of plasmid DNA onto functionalized carbon nanotubes: toward the construction of nanotube-based gene delivery vectors. J Am Chem Soc 127: 4388-4396

33. Pantarotto D, Singh R, McCarthy D, Erhardt M, Briand JP, et al. (2004) Functionalized carbon nanotubes for plasmid DNA gene delivery. Angew Chem Int Ed Engl 43: 5242-5246.

34. Biris AS, Boldo, D, Palmer J, Monroe WT, Mahmood M, et al. (2009) Nanophotothermolysis of multiple scattered cancer cells with carbon nanotubes guided by time-resolved infrared thermal imaging. J Biomed Opt 14: 021007.

35. Vázquez E, Prato M (2009) Carbon nanotubes and microwaves: interactions, responses, and applications. ACS Nano 3: 3819-3824.

36. Gannon CJ, Cherukuri P, Yakobson BI, Cognet L, Kanzius JS, et al. (2007) Carbon nanotube-enhanced thermal destruction of cancer cells in a noninvasive radiofrequency field. Cancer 110: 2654-2665.

37. Takahashi K, Tanabe K, Ohnuki M, Narita M, Ichisaka T, et al. (2007) Induction of pluripotent stem cells from adult human fibroblasts by defined factors. Cel 131: 861-872.

38. Han Z, Kong H, Meng J, Wang C, Xie S, et al. (2009) Electrospun aligned nanofibrous scaffold of carbon nanotubes-polyurethane composite for endothelial cells. J Nanosci Nanotechnol 9: 1400-1402.

39. Sucapane A, Cellot G, Prato M, Giugliano M, Parpura V, et al. (2009) Interactions between cultured neurons and carbon nanotubes: a nanoneuroscience vignette. J Nanoneurosci 1: 10-16.

40. Dubin RA, Callegari G, Kohn J, Neimark A (2008) Carbon nanotube fibers are compatible with Mammalian cells and neurons. IEEE Trans Nanobioscience 7: 11-14.

41. Mattson MP, Haddon RC, Rao AM (2000) Molecular functionalization of carbon nanotubes and use as substrates for neuronal growth. J Mol Neurosci 14: 175182

42. Khang D, Park GE, Webster TJ (2008) Enhanced chondrocyte densities on carbon nanotube composites: the combined role of nanosurface roughness and electrical stimulation. J Biomed Mater Res A 86: 253-260.

43. Cao Y, Zhou YM, Shan Y, Ju HX, Xue XJ (2007) Preparation and characterization of grafted collagen-multiwalled carbon nanotubes composites. J Nanosci Nanotechnol 7: 447-451.

44. MacDonald RA, Laurenzi BF, Viswanathan G, Ajayan PM, Stegemann JP (2005) Collagen-carbon nanotube composite materials as scaffolds in tissue engineering. J Biomed Mater Res A 74: 489-496.

45. Chao TI, Xiang S, Chen CS, Chin WC, Nelson AJ, et al. (2009) Carbon nanotubes promote neuron differentiation from human embryonic stem cells. Biochem Biophys Res Commun 384: 426-430.

46. Narita N, Kobayashi $Y$, Nakamura H, Maeda K, Ishihara A, et al. (2009) Multiwalled carbon nanotubes specifically inhibit osteoclast differentiation and function. Nano Lett 9: 1406-1413.

47. Saito N, Usui Y, Aoki K, Narita N, Shimizu M, et al. (2009) Carbon nanotubes: biomaterial applications. Chem Soc Rev 38: 1897-1903.

48. Saito N, Usui Y, Aoki K, Narita N, Shimizu M, et al. (2008) Carbon nanotubes for biomaterials in contact with bone. Curr Med Chem 15: 523-527.

49. Balani K, Anderson R, Laha T, Andara M, Tercero J, et al. (2007) Plasmasprayed carbon nanotube reinforced hydroxyapatite coatings and their interaction with human osteoblasts in vitro. Biomaterials 28: 618-624.

50. Giannona S, Firkowska I, Rojas-Chapana J, Giersig M (2007) Vertically aligned carbon nanotubes as cytocompatible material for enhanced adhesion and proliferation of osteoblast-like cells. J Nanosci Nanotechnol 7: 1679-1683.

51. Wang W, Watari F, Omori M, Liao S, Zhu Y, et al. (2007) Mechanical properties and biological behavior of carbon nanotube/polycarbosilane composites for implant materials. J Biomed Mater Res B Appl Biomater 82: 223-230. 
Citation: Usui Y, Haniu H, Tsuruoka S, Saito N (2012) Carbon Nanotubes Innovate on Medical Technology. Med chem 2: 001-006. doi:10.4172/21610444.1000105

52. Shi X, Hudson JL, Spicer PP, Tour JM, Krishnamoorti R, et al. (2006) Injectable nanocomposites of single-walled carbon nanotubes and biodegradable polymers for bone tissue engineering. Biomacromolecules 7: 2237-2242.

53. Zanello LP, Zhao B, Hu H, Haddon RC (2006) Bone cell proliferation on carbon nanotubes. Nano Lett 6: 562-567.

54. Nakabayashi N, Ishihara K, Iwasaki Y (1999) Biomaterial. Japan Society of Medical Electronics and Biological Engineering. (Edn) Corona Publishing Co.,Ltd., Tokyo.

55. Goodman SB, Ma T (2010) Cellular chemotaxis induced by wear particles from joint replacements. Biomaterials 31: 5045-5050.

56. Rahaman MN (2008) Sintering of ceramics. CRC Press, Boca Raton.

57. Carter CB, Norton MG (2007) Ceramic Materials Science and Engineering. Springer, New York.

58. Krell A, Klimake J (2006) Effects of the Homogeneity of Particle Coordination on Solid-State Sintering of Transparent Alumina. J Am Ceram Soc 89: 19851992.

59. Ueda N, Yamakami T, Yamaguchi T, Kitajima K, Usui Y, et al. (2010) Fabrication and mechanical properties of high-dispersion-treated carbon nanofiber/alumina composites. J Ceram Soc Jpn 118: 847-854

60. Usui Y, Aoki K, Narita N, Murakami N, Nakamura I, et al. (2008) Carbon nanotubes with high bone-tissue compatibility and bone-formation acceleration effects. Small 4: 240-246.

61. Saito N, Okada T, Horiuchi H, Murakami N, Takahashi J, et al. (2001) A biodegradable polymer as a cytokine delivery system for inducing bone formation. Nat Biotechnol 19: 332-335.
62. Urist MR (1965) Bone Formation by Autoinduction. Science 150: 893-899.

63. Akasaka T, Warari F, Sato Y, Tohji K (2006) Apatite Formation on Carbon Nanotubes. Mater Sci Eng C 26: 675-678.

64. Beg S, Rizwan M, Sheikh AM, Hasnain MS, Anwer K, et al. (2011) Advancement in carbon nanotubes: basics, biomedical applications and toxicity. J Pharm Pharmacol 63: 141-163.

65. Demming A (2011) Nanotechnology under the skin. Nanotechnology 22 260201.

66. van der Zande M, Junker R, Walboomers XF, Jansen JA (2011) Carbon nanotubes in animal models: a systematic review on toxic potential. Tissue Eng Part B Rev 17: 57-69.

67. Lee Y, Geckeler KE (2010) Carbon nanotubes in the biological interphase: the relevance of noncovalence. Adv Mater 22: 4076-4083.

68. Kostarelos K, Bianco A, Prato M (2009) Promises, facts and challenges for carbon nanotubes in imaging and therapeutics. Nat Nanotechnol 4: 627-633.

69. Liu Z, Davis C, Cai W, He L, Chen X, et al. (2008) Circulation and long-term fate of functionalized, biocompatible single-walled carbon nanotubes in mice probed by raman spectroscopy. Proc Natl Acad Sci USA 105: 1410-1415.

70. Schipper ML, Nakayama-Ratchford N, Davis CR, Kam NW, Chu P, et al. (2008) A pilot toxicology study of single-walled carbon nanotubes in a small sample of mice. Nat Nanotechnol 3: 216-221.

71. Fiorito S, Serafino A, Andreola F, Togna A, Togna G (2006) Toxicity and biocompatibility of carbon nanoparticles. J Nanosci Nanotechnol 6: 591-599.

72. Hara K, Aoki K, Usui Y, Shimizu M, Narita N, et al. (2011) Evaluation of CNT toxicity in comparison to tattoo ink nanoparticles for use as a biomaterial. Mater Today 14: 434-440. 